\title{
THE METHOD OF IDENTIFICATION THE FAILURE RISK ON WATER SUPPLY NETWORKS
}

\section{METODA IDENTYFIKACJI RYZYKA AWARII SIECI WODOCIĄGOWYCH}

\author{
Barbara Tchórzewska-Cieślak, Izabela Piegdoń \\ Rzeszów University of Technology \\ cbarbara@prz.edu.pl,piegi@prz.edu.pl,
}

\begin{abstract}
Daily exploitation of the water network, collecting of data concerning the failure of water pipes and knowledge of the repair team are the basis of the data used in the process of effectively removing and identifying failures. The paper proposes a methodology to identify the risk of failure of the water supply system that uses risk indexes according to the proposed three-stage scale of risk levels. An example of application methods for the actual operational data broken down by analysis and risk assessment for bus cables and a separate analysis for the distribution network.
\end{abstract}

Keywords: water supply network, failure, risk

Streszczenie: Codzienna eksploatacja sieci, zbiór danych dotyczących awaryjności przewodów oraz wiedza pracowników stanowia baze danych wykorzystywanych $w$ procesie efektywnego usuwania $i$ identyfikowania awarii. W pracy zaproponowano metodyke identyfikacji ryzyka awarii sieci wodociagowej, wykorzystujaca indeksy ryzyka zgodnie z zaproponowana trójstopniowa skala poziomów ryzyka. Przedstawiono przyktad aplikacyjny metody dla rzeczywistych danych eksploatacyjnych $z$ podziatem na analize $i$ ocene ryzyka dla przewodów magistralnych oraz osobna analize dla sieci rozdzielczej.

Slowa kluczowe: sieć wodociagowa, awaryjność, ryzyko 


\section{THE METHOD OF IDENTIFICATION THE FAILURE RISK ON WATER SUPPLY NETWORKS}

\section{Introduction}

Collective water supply systems (CWSS) are interrelated objects and elements being an integral whole. Their aim is to provide consumers with water safe for consumption, in reliable and safe way. One of the basic objects of CWSS is water supply network constituting the water distribution system in the area of water supply. Water supply network transports water from a source to individual customers, co-operating with water pumping stations, hydrophores and water supply tanks. Depending on the nature of water supply area and, most of all, its span, altitude conditions as well as the number and the distance from the source, water supply system can operate in various hydraulic systems. The design process of water supply system is a complex process and during its execution one should take into account the economic, technical and reliability aspects. The system of water supply network should provide a stable flow of water at the necessary pressure, providing favourable conditions to ensure biological and chemical stability of water [12], [13], [19], [5], [1]. Water quality in the water supply system can not change flowing from the treatment plant to customers. The definition of water supply reliability is:

"Water supply reliability relies on ensuring stable conditions which allow to cover current and prospective demand for water in sufficient quantity and required quality at any time convenient for water consumers".

At the macro scale, safety concerning water supply is defined as a state of water management that allows to cover current and future customers demands for water, in a technically and economically justified way, and by the requirements for the protection of the aquatic environment.

The primary and basic subject to which the notion of water safety is concerned is a consumer [18]. The secondary subject is a supplier - a producer of water. In this respect, one can consider the risk of the consumer and the risk of the producer [10], [6]. The important element in this regard is also the environmental aspect and the principles of sustainable development in widely understood water management.

Many regulations defines the producer's risk through a systematic error correctness of physical and chemical analysis and a random error - precision of physical and chemical analysis [20]. Error in evaluation of the first kind means disqualifying water which quality meets standard requirements and refers to the risk of the producer. Error in evaluation of the second kind means accepting water which quality does not meet standard requirements and refers to the risk of the consumer. The consequences of an error of the second kind of water quality assessment are more severe, particularly in relation to health of the individual water consumers.

Water supply safety can also be considered according to the criteria of specified time perspective:

- current short-time safety, the so-called operating,

- seasonal safety associated with the seasons,

- medium-time safety expected in the coming years (up to 5 years),

- long-term safety planned for the prospect of above 20 years - strategic. 
The main aim of this work is to present the methodology of indexing the risk of water pipes failure. The methodology is based on the analysis and assessment of the risk of failure taking into account a diameter which is a factor characterizing pipes. An example of application of indexing the risk of failure has been made separately for the main pipes and for the distribution pipes.

\section{The method to identify risk of failure of water supply network}

Reliability and safety of the CWSS operation are achieved through risk management at every stage of the " system life" - at the design stage, during construction and operation. In the analyses and assessments of water supply system functioning it has become a paradigm to accept risk in form $r=f(t)$ as a measure of loss of safety [4], [7], [15], [14], [8], [3].

Safety management is carried out by risk analysis, and in particular:

- risk identification,

- evaluation (risk assessment),

- rules for dealing with risk,

- risk financing.

Risk identification generally means the analysis of risk factors, their sources, determination of the so called weak points and consequences (effects) of their occurrence. The most often this analysis concerns the undesirable events, which can appear in the system with the specified probability „P” and cause the specified losses „C", which can result in the loss of the system safety. These events can have a single (incidental) character, it can be a series of events or a single event triggering a series of next events (the so called domino effect) [5]. The value of the risk of failure is also affected by the system of protection against the undesirable events characterized by the parameter of susceptibility to the threat , $V^{\prime \prime}$ or the protection parameter , $O$ ” [2], [9].

The following formula to determine the risk of failure of water supply network was adopted:

$$
r=P \cdot C \cdot V
$$

where:

$P$ - probability of the occurrence of failure,

$C$ - losses caused by failure,

$V$-system vulnerability associated with the occurrence of failure.

The criterion values for the individual risk parameters are adopted individually for the particular water supply system, taking into account its specific character or hydraulic structure. The knowledge of experts that is described, among others, in [11], [16], [17] canx be used. 
The method of identification the failure risk on water supply networks Metoda identyfikacji ryzyka awarii sieci wodociagowych

Point weights for the individual risk parameters were adopted as follows:

- for the parameter $P$ :

- 1 - very unlikely,

- 2 - unlikely,

- 3-medium probability,

- 4-moderate probability,

- 5 - very likely.

- for the parameter $C$ :

- 1 - very small,

- 2 - small,

- 3 - medium,

- 4 - large,

- 5 - very large.

- for the parameter $V$ :

- 1 - small,

- 2 - medium,

- 3 - large.

The risk evaluation process involves the determination (assessment) of its numerical value according to (1) and comparing it with the assumed criteria values. The most common scale of risk levels is a three-stage scale according to the rule [5]:

- tolerable risk- $r T$,

- controlled risk - $r K$,

- unacceptable risk - $r N$.

The risk matrix for the parameter $V=1$ can be presented as follows:

$$
\left|r_{i, j, k}\right|=\left|\begin{array}{ccccc}
1 & 2 & 3 & 4 & 5 \\
2 & 4 & 6 & 8 & 10 \\
3 & 6 & 9 & 12 & 15 \\
4 & 8 & 12 & 16 & 20 \\
5 & 10 & 15 & 20 & 25
\end{array}\right|
$$

The risk matrix for the parameter $V=2$ can be presented as follows:

$$
\left|r_{i, j, k}\right|=\left|\begin{array}{ccccc}
2 & 4 & 6 & 8 & 10 \\
4 & 8 & 12 & 16 & 20 \\
6 & 12 & 18 & 24 & 30 \\
8 & 16 & 24 & 32 & 40 \\
10 & 20 & 30 & 40 & 50
\end{array}\right|
$$


The risk matrix for the parameter $V=3$ can be presented as follows:

$$
\left|r_{i, j, k}\right|=\left|\begin{array}{ccccc}
3 & 6 & 9 & 12 & 15 \\
6 & 12 & 18 & 24 & 30 \\
9 & 18 & 27 & 36 & 45 \\
12 & 24 & 36 & 48 & 60 \\
15 & 30 & 45 & 60 & 75
\end{array}\right|
$$

The value of the risk and every risk index were determined based on the assumption that in the analysed year in the main network and in the distribution network occurred , $i$ " failures for which risk analysis showed the risk on a tolerable level,,$j$ " failures for which risk analysis showed the risk on a controlled level and ,$k$ " failures for which risk analysis showed the risk on an unacceptable level.

According to the formula (1) the individual risk parameters contained in the columns of the matrix give a result testifying the value of the risk of failure in water supply network. The next step, for the purposes of risk assessment, is to compare the obtained values with the criteria and risk categories proposed in Table 1.

Table 1. Risk criteria values

\begin{tabular}{|cc|}
\hline Risk value & Risk category \\
\hline $1 \div 10$ & Controlled \\
\hline $11 \div 25$ & Tolerable \\
\hline $26 \div 75$ & Unacceptable \\
\hline
\end{tabular}

The analysis of results may be performed based on:

- the percentage distribution of risk according to risk category (type),

- the distribution of unacceptable risk,

- the susceptibility distribution according to the distribution of unacceptable risk,

- giving the unacceptable risk index - the ratio of the unacceptable risk to the total number of risk in a given category, it shows which types of risk is moving toward an unacceptable risk.

The individual indices of risk for the individual risk were calculated according to the following formulas:

- the tolerable risk index $\operatorname{Ir} T$ according to formula:

$$
I r T=\frac{\sum_{i} r T_{i}}{\sum r_{T K N}}
$$

- the controlled risk index $\operatorname{Ir} K$ according to formula:

$$
I r K=\frac{\sum_{j} r K_{j}}{\sum r_{T K N}}
$$


The method of identification the failure risk on water supply networks Metoda identyfikacji ryzyka awarii sieci wodociagowych

- the unacceptable risk index $\operatorname{IrN}$ according to formula:

$$
I r N=\frac{\sum_{k} r N_{k}}{\sum r_{T K N}}
$$

where:

$$
\sum r_{T K N}=\sum_{i} r T_{i}+\sum_{j} r K_{j}+\sum_{k} r N_{k}
$$

$\sum_{i} r T_{i}$ - the sum of the risk , $i$ ' on a tolerable level at the analysed period of time $\Delta \mathrm{t}$,

$\sum_{j} r K_{j}$ - the sum of the risk,,$j$ " on a controlled level at the analysed period of time $\Delta \mathrm{t}$,

$\sum_{k} r N_{k}$ - the sum of the risk , $k$ ' on an unacceptable level at the analysed period of time $\Delta t$.

$\operatorname{IrT} \quad$ - the tolerable risk index,

IrK - the controlled risk index,

IrN - the unacceptable risk index.

\section{Application example}

The analysed water supply network currently supplies approx. 190 thousand residents. The capacity of the intake is 84 thousand $\mathrm{m}^{3} / \mathrm{d}$, with the average daily water consumption approx. 35,6 thousand $\mathrm{m}^{3} / \mathrm{d}$ (in 2013). The application example was made for the water supply network (main and distribution) with a total length of $579,8 \mathrm{~km}$.

Based on the identification of risk factors and detailed analysis of failures for the water supply network divided into main and distribution network, based on data from the failure log in 2014, a number of risk at a particular level was determined and then the individual indices of risk were determined.

The risk analysis was performed separately for the main network (where 33 failures were reported) and the distribution network (where 67 failures were reported) by the three parameter method according to the formula (1).

The failure risk analysis was carried out on the basis of experts and workers knowledge and the available professional literature.

On the basis of the functioning water supply system, the consequences of every failure on the main network and the distribution network, the point weights were assigned to every parameter $P, C$ and $V$, according to the equation (1).

As a factor characterizing every failure, a diameter of the pipe where the failure occurred, was adopted. Point description criteria for every failure of the water supply system were shown in Tables 2 and 3. 
Table 2. Point description criteria for failures on water main network

\begin{tabular}{|cccc|}
\hline Diameter & Parameter $P$ & Parameter $C$ & Parameter $V$ \\
\hline 300 & 2 & 2 & 2 \\
\hline 325 & 1 & 2 & 2 \\
\hline 350 & 2 & 3 & 1 \\
\hline 400 & 5 & 3 & 1 \\
\hline 500 & 3 & 4 & 1 \\
\hline 800 & 1 & 5 & 1 \\
\hline
\end{tabular}

Table 3. Point description criteria for failures on water distribution network

\begin{tabular}{|cccc|}
\hline Diameter & Parameter $P$ & Parameter $C$ & Parameter $V$ \\
\hline 100 & 5 & 1 & 3 \\
\hline 110 & 2 & 1 & 3 \\
\hline 150 & 5 & 1 & 3 \\
\hline 160 & 2 & 2 & 2 \\
\hline 200 & 2 & 2 & 2 \\
\hline 225 & 1 & 2 & 2 \\
\hline 250 & 3 & 2 & 2 \\
\hline
\end{tabular}

Using the formula (1) the risk values for each diameter were calculated. The results are summarized in Tables 4 and 5.

Tabela 4. The values of risk of failure on the main network

\begin{tabular}{|ccc|}
\hline Diameter & Risk value & Risk category \\
\hline 300 & 8 & Tolerable \\
\hline 325 & 4 & Tolerable \\
\hline 350 & 6 & Controlled \\
\hline 400 & 15 & Controlled \\
\hline 500 & 12 & Controlled \\
\hline 800 & 5 & Tolerable \\
\hline
\end{tabular}

Table 5. The values of risk of failure on the distribution network

\begin{tabular}{|ccc|}
\hline Diameter & Risk value & Risk category \\
\hline 100 & 15 & Controlled \\
\hline 110 & 6 & Tolerable \\
\hline 150 & 15 & Controlled \\
\hline 160 & 8 & Tolerable \\
\hline 200 & 8 & Tolerable \\
\hline 225 & 4 & Tolerable \\
\hline 250 & 12 & Controlled \\
\hline
\end{tabular}


The method of identification the failure risk on water supply networks Metoda identyfikacji ryzyka awarii sieci wodociagowych

Based on the results obtained in Tables 4 and 5, the sum of the risk on the main network and the distribution network necessary to determine the indexes of each of the risk, were determined according to the formula (5).

The sum of the risk on the main network is:

$$
\sum r_{\text {TKNmain }}=8+4+6+15+12+5=50
$$

The sum of the risk on the distribution network is:

$$
\sum r_{\text {TKNdistribution }}=15+6+15+8+8+4+12=68
$$

On the basis of the sum of the risk, the indexes of the particular risk were determined according to the formulas (2), (3), (4). Results has been shown in Table 6.

Table 6. Results of the analysis of different types of risk

\begin{tabular}{|cc|cccc|ccc|}
\hline \multirow{2}{*}{ Ip } & $\begin{array}{c}\text { Type of water } \\
\text { network }\end{array}$ & \multicolumn{4}{|c|}{ Risk value in each scale } & \multicolumn{4}{|c|}{ Risk index } \\
\cline { 3 - 9 } & $\boldsymbol{r} \boldsymbol{T}_{\boldsymbol{i}}$ & $\boldsymbol{r} \boldsymbol{K}_{\boldsymbol{j}}$ & $\boldsymbol{r} \boldsymbol{N}_{\boldsymbol{k}}$ & $\sum$ & $\boldsymbol{I} \boldsymbol{r} \boldsymbol{I}$ & $\boldsymbol{I} \boldsymbol{r} \boldsymbol{I} \boldsymbol{N} \boldsymbol{N}$ \\
\hline 1 & Main & 3 & 3 & 0 & 6 & 0,34 & 0,66 & 0 \\
\hline 2 & Distribution & 4 & 3 & 0 & 7 & 0,38 & 0,62 & 0 \\
\hline
\end{tabular}

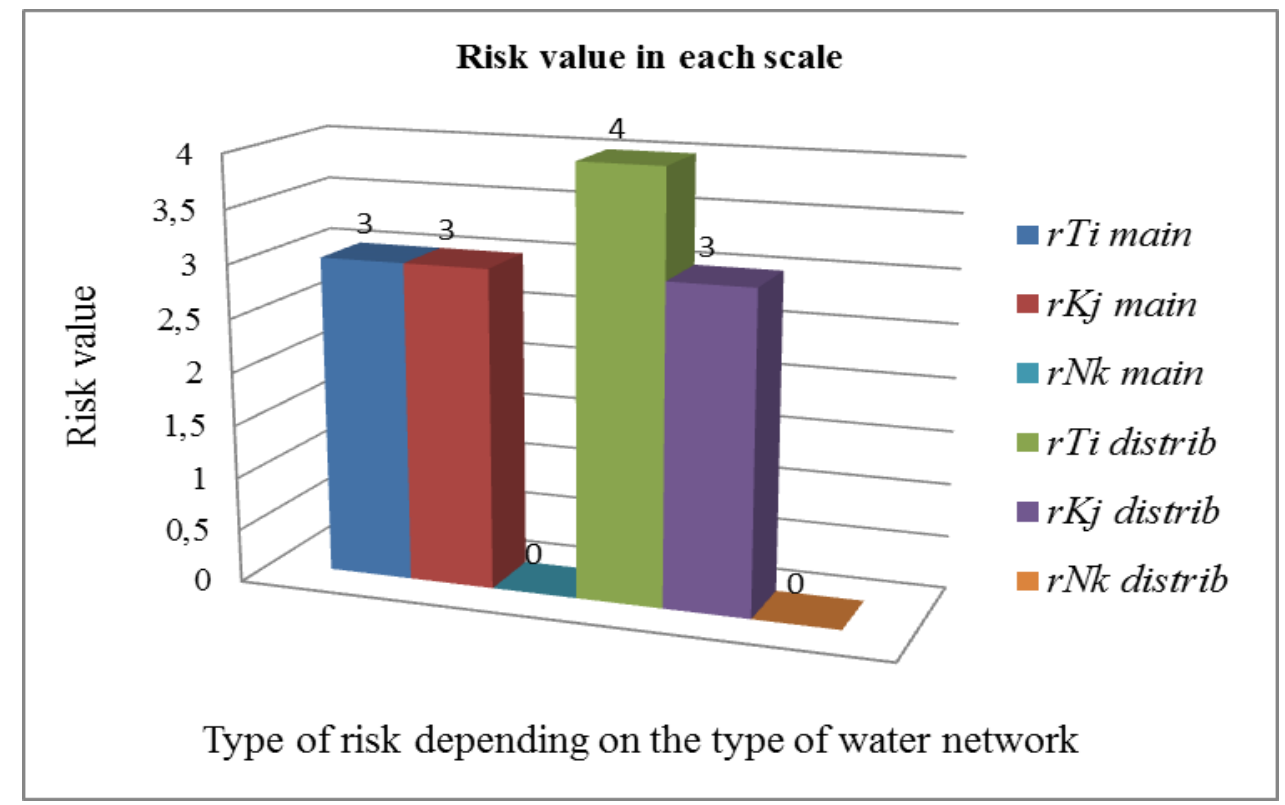

Fig.1. Presentation of the number of risk and its type depending on the water network 


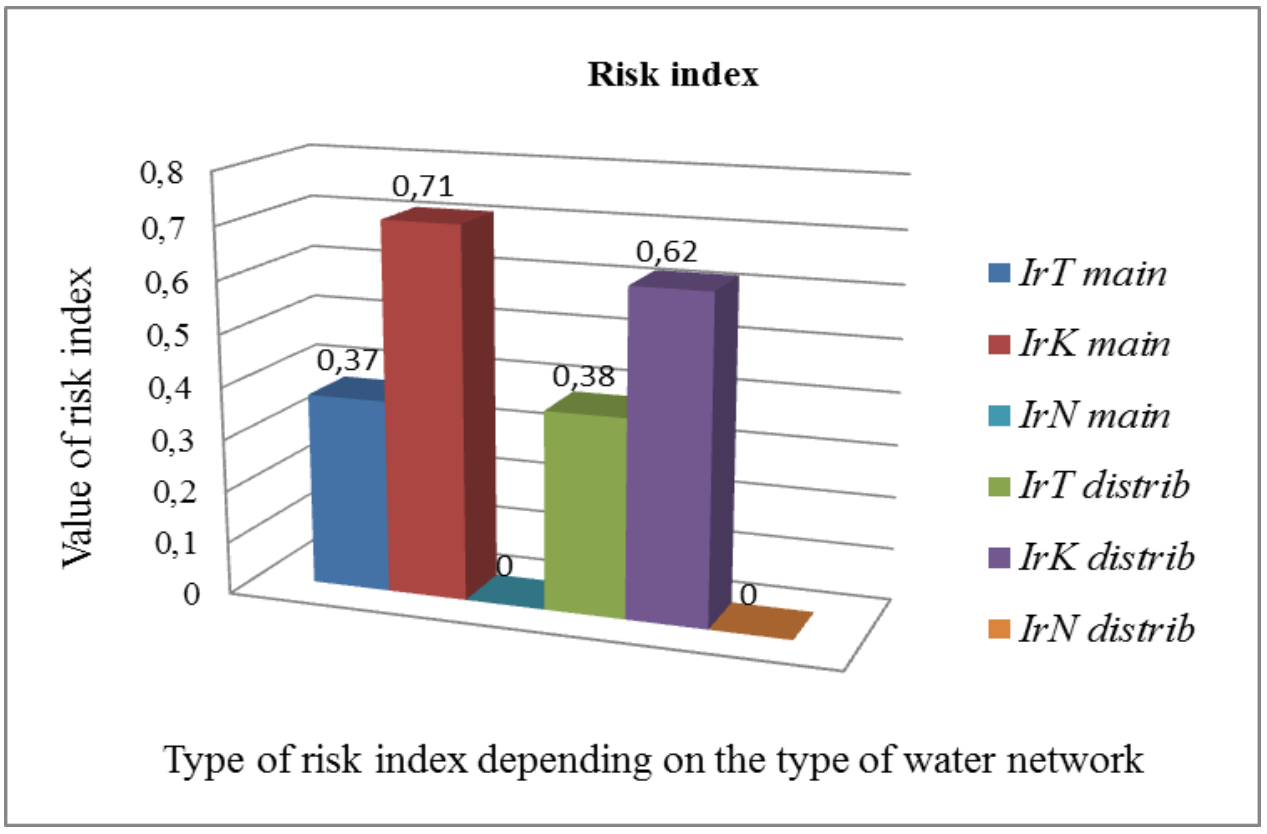

Fig.2. Presentation of the index values of the risk depending on the type of water network

\section{Conclusions}

The proposed method shows the percentage distribution of the identified risk values. The method takes into account the frequency of failure on the water supply pipe with a specified diameter, the average repair costs and estimated time when the damaged pipe is excluded from use due to the necessity of its renovation. The results of the risk indices for various types of networks determine the risk of failure in the form of percentage. This method allows to create clear and readable rank describing the failure rate of water pipes. Moreover, it can be adapted for every water company that keeps a record of failures.

\section{Bibliografia}

[1] Imran S. A. Sadiq R., Kleiner Y.,, Managing the impact of changing treatment practices on distribution system water quality, WCWWA 60 th Anniversary Conference, Regina, 2008

[2] Kaplan S. Garrick B. J., On the quantative definition of risk Risk Analysis, 1(1)/1981, s. 11-27.

[3] Kleiner Y. Rajani B., Sadiq R., Failure risk management of buried infrastructure using fuzzy-based techniques, Journal of Water Supply Research and Technology - AQUA, International Water Association Publishing, 55(2)/2006, s. 81-94. 
The method of identification the failure risk on water supply networks Metoda identyfikacji ryzyka awarii sieci wodociagowych

[4]. Kołowrocki K. Smalko Z., Safety and reliability of a three-state system at variable operation conditions, Scientific problems of machines operation and maintenance, Komitet Budowy Maszyn PAN, 2(166)/2011, s. 47-54.

[5]. Papciak D. Zamorska J., Kaleta J., Puszkarewicz A.,, Effect of Manganese(II) on the Time of Biofilm Formation and on the Effectiveness of Ammonium Nitrogen Removal from Water In Biofiltration Process, Polish Journal of Environmental Studies, 2/2009, s. 43-50.

[6]. Piegdoń I. Tchórzewska-Cieślak B., Matrix analysis of risk of interruptions in water supply in terms of consumer safety, Journal of KONBiN. 2012, Wydawnictwo Instytutu Technicznego Wojsk Lotniczych, Warszawa. p. 125-140.

[7]. Rak J., Podstawy bezpieczeństwa systemów zaopatrzenia $w$ wodę, Komitet Inżynierii Środowiska PAN, Lublin, 2005.

[8]. Rak J., Selected problems of water supply safety, Environment Protection Engineering, Wroclaw University of Technology, the Department of Environmental Engineering, 35(2)/2009, s. 29-35.

[9]. Rak J., A study of the qualitative methods for risk assessment in water supply systems, Environment Protection Engineering, Oficyna Wydawnicza Politechniki Wrocławskiej, 3-4/2003, s. 123-134.

[10]. Rak J. Tchórzewska-Cieślak B., Ryzko w eksploatacji systemów zbiorowego zaopatrzenia $w$ wode, Wydawnictwo Seidel-Przywecki Sp. z o.o., Warszawa, 2013.

[11]. Studziński A., Amount of labour of water conduit repair, Proceedings of the European Safety and Reliability Conference, ESREL 2013, Taylor \& Francis Group, 2014, s. 2081-2084.

[12]. Świderska -Bróż M Wolska M., Ocena wtórnego zanieczyszczenia niestabilnej chemicznie wody $w$ systemie dystrybucji, Ochrona Środowiska PZiTS O/Dolnośląski, 4/2005, s. 35-38.

[13]. Świderska -Bróż M., Skutki obecności biofilmu w systemach dystrybucji wody przeznaczonej do spożycia przez ludzi, Ochrona Środowiska, PZiTS O/Dolnośląski, 1/2012, s. 9-12.

[14]. Tchórzewska-Cieślak B., Risk management system in water-pipe network functioning, Reliability And Societal Safety, Taylor \& Francis, 3/2008, s. 2463-2472.

[15]. Tchórzewska-Cieślak B., Water consumer safety in water distribution system, Environmental Engineering III, Dudzińska M. R. Pawłowski L., Pawłowski A., Editor. 2010, Taylor \& Francis Group, London. p. 527-532. 
[16]. Tchórzewska Cieślak B. Boryczko K., Piegdoń I.,, Possibilistic risk analysis of failure in water supply network, Proceedings of the European Safety and Reliability Conference, ESREL 2014, 2014, s. 1473-1480.

[17]. Tchórzewska Cieślak B. Szpak D., A proposal of a method for water supply safety analysis and assessment, Ochrona Środowiska, 37(3)/2015, s. 43-47.

[18]. World Health Organization, Water Safety Plans. Managing drinkingwater quality from catchment to consumer, Water, Sanitation and Health. Protection and the Human Environment World Health Organization, Geneva, 2005.

[19]. Rozporządzenie Ministra Zdrowia z dnia 13 listopada 2015 r. w sprawie wymagań dotyczących jakości wody przeznaczonej do spożycia przez ludzi (Dz. U. z dnia 27.11.2015 r. poz.1989).

[20]. PN-N-18002-2011 - Systemy zarządzania bezpieczeństwem i higieną pracy. Ogólne wytyczne do oceny ryzyka zawodowego.

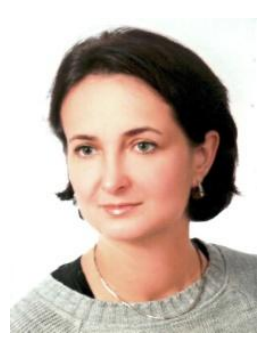

Barbara Tchórzewska-Cieślak is currently working as a professor at Rzeszow University of Technology, Department of Water Supply and Sewage Systems. Specialization - water supply systems, reliability and safety analyses of municipal systems, risk assessment in water supply systems.(Share: 50\%).

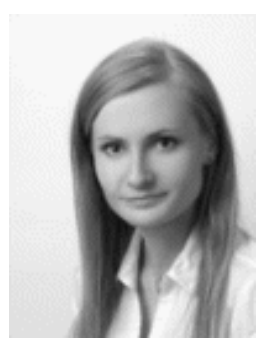

mgr inż. Izabela Piegdoń is currently working at Rzeszow University of Technology, Department of Water Supply and Sewage Systems. Specialization - reliability and safety of systems engineering, information technologies in the management of water distribution systems. (Share: 50\%). 
The method of identification the failure risk on water supply networks Metoda identyfikacji ryzyka awarii sieci wodociagowych

\section{METODA IDENTYFIKACJI RYZYKA AWARII SIECI WODOCIĄGOWYCH}

\section{Wprowadzenie}

Systemy zbiorowego zaopatrzenia w wodę (SZZW) stanowią powiązane ze sobą obiekty i elementy, stanowiące integralną całość. Jego celem jest dostarczenie konsumentom wody zdatnej do spożycia w sposób niezawodny oraz bezpieczny. Jednym z podstawowych obiektów SZZW jest sieć wodociągowa stanowiąca układ dystrybucji wody w obszarze zasilania w wodę. Sieć wodociągowa transportuje wodę od źródła do poszczególnych odbiorców, współpracując w tym zakresie z pompowniami wodociągowymi, hydroforniami oraz zbiornikami wodociągowymi. W zależności od charakteru obszaru zasilania a przede wszystkim jego rozpiętości, warunków wysokościowych a także liczby oraz odległości od źródła wody siec wodociągowa może pracować w rożnych układach hydraulicznych. Proces projektowania układu sieci wodociągowej jest procesem złożonym a w trakcie jego realizacji powinno się brać pod uwagę aspekty techniczne ekonomiczne oraz niezawodnościowe. Układ sieci wodociągowej powinien zapewniać stabilny przepływ wody pod wymaganym ciśnieniem, zapewniając jednocześnie korzystne warunki dla zapewnienia stabilności biologicznej i chemicznej wody [12], [13], [19], [5], [1]. Jakość wody w sieci wodociągowej nie może się zmieniać na drodze przepływu od stacji uzdatniania do odbiorców. Definicja niezawodności dostawy wody brzmi:

„Niezawodność dostawy wody polega na zapewnieniu stabilnych warunków, umożliwiajacych pokrycie bieżacego $i$ perspektywicznego zapotrzebowania na wode $w$ odpowiedniej ilości $i$ wymaganej jakości $w$ dowolnym, dogodnym dla konsumentów wody".

Pojęcie bezpieczeństwa $\mathrm{W}$ skali makro $\mathrm{w}$ zakresie zaopatrzenia $\mathrm{W}$ wodę definiowane jest jako stan gospodarki wodnej umożliwiający pokrycie bieżącego i perspektywicznego zapotrzebowania odbiorców na wodę, w sposób technicznie i ekonomicznie uzasadniony, przy zachowaniu wymagań ochrony środowiska wodnego.

Pierwotnym i podstawowym podmiotem, którego dotyczy pojęcie bezpieczeństwa wodnego, jest konsument [18]. Wtórnym podmiotem jest dostawca - producent wody. W tym względzie można rozpatrywać ryzyko konsumenta i producenta [10], [6]. Ważnymi elementami w tym zakresie są również: aspekt środowiskowy oraz zasady zrównoważonego rozwoju w szeroko rozumianej gospodarce wodnej.

Wiele unormowań definiuje ryzyko producenta poprzez błąd systematyczny poprawność analizy fizykochemicznej i błąd przypadkowy - precyzję analizy fizykochemicznej [20]. Błąd oceny pierwszego rodzaju polega na dyskwalifikacji jakości wody spełniającej wymagania normatywne i odnosi się do ryzyka producenta. Błąd oceny drugiego rodzaju polega na akceptacji jakości wody 
niespełniającej wymagań normatywnych i odnosi się do ryzyka konsumenta. Konsekwencje błędu drugiego rodzaju oceny jakości wody są bardziej dotkliwe, szczególnie w odniesieniu do zdrowia indywidualnych konsumentów wody.

Bezpieczeństwo zaopatrzenia $\mathrm{w}$ wodę można również rozpatrywać według kryterium określonej perspektywy czasowej:

- bezpieczeństwo krótkookresowe w czasie bieżącym, tzw. operacyjne,

- bezpieczeństwo sezonowe związane z porami roku,

- bezpieczeństwo średniookresowe przewidywane na najbliższe lata (do 5 lat),

- bezpieczeństwo długookresowe planowane na perspektywę powyżej 20 lat - strategiczne.

Głównym celem pracy jest przedstawienie metodyki indeksowania ryzyka awarii przewodów wodociągowych. Metodyka bazuje na analizie i ocenie ryzyka awarii z uwzględnieniem czynnika charakteryzującego przewody jakim jest średnica. Przykład aplikacyjny indeksowania ryzyka awarii został sporządzony oddzielnie dla przewodów magistralnych oraz oddzielnie dla przewód rozdzielczych.

\section{Metoda identyfikacji ryzyka awarii sieci wodociągowej}

Zapewnienie niezawodności funkcjonowania i bezpieczeństwa SZZW osiąga się poprzez zarządzanie ryzykiem w każdej fazie „Życia systemu” - na etapie projektowania, w czasie budowy i eksploatacji. W analizach i ocenach funkcjonowania systemów wodociągowych paradygmatem stało się przyjmowanie jako miary utraty bezpieczeństwa funkcji ryzyka postaci $r=f(t)$ [4], [7], [15], [14], [8], [3].

Zarządzanie bezpieczeństwem przeprowadza się poprzez analizę ryzyka, a w szczególności:

- identyfikacje ryzyka,

- ocenę (szacowanie ryzyka),

- zasady postępowania z ryzykiem,

- finansowanie ryzyka.

Identyfikacja ryzyka polega głównie na analizie czynników ryzyka, ich źródeł, określenie tzw. słabych punktów oraz konsekwencji (skutków) ich występowania. Najczęściej analiza ta dotyczy zdarzeń niepożądanych, które mogą pojawić się $\mathrm{w}$ systemie $\mathrm{z}$ określonym prawdopodobieństwem , $P$ ” i wywołać określone straty „C", co może skutkować utratą bezpieczeństwa systemu. Zdarzenia te mogą mieć charakter pojedynczy (incydentalny), może być to seria zdarzeń lub pojedyncze zdarzenie wywołujące serię następnych (tzw. efekt domina) [7]. Na wartość ryzyka awarii ma również wpływ system zabezpieczeń przed zdarzeniami niepożądanymi charakteryzowany parametrem podatności na zagrożenie,$V^{\prime \prime}$ lub parametrem ochrony , $O^{\prime \prime}[2],[9]$. 
The method of identification the failure risk on water supply networks Metoda identyfikacji ryzyka awarii sieci wodociagowych

Przyjęto następująca formułę dla wyznaczenia wartości ryzyka awarii sieci wodociągowej:

$$
r=P \cdot C \cdot V
$$

gdzie:

$P$ - prawdopodobieństwo (ang. probability) wystąpienia zdarzenia awaryjnego,

$C$ - wartość strat (ang. loss) wywołanych przez zdarzenie awaryjne,

$V$ - podatność systemu (ang. vulneralibility) związana z wystąpieniem zdarzenia awaryjnego.

Wartości kryterialne dla poszczególnych parametrów ryzyka przyjmuje się indywidualnie dla konkretnego systemu wodociągowego, uwzględniając przy tym jego specyfikę czy strukturę hydrauliczną. Można wykorzystać przy tym wiedzę ekspercką opisaną $m$ in. w pracach [17], [11], [16].

Wagi punktowe dla poszczególnych parametrów ryzyka przyjęto następująco:

- dla parametru $P$ :

- 1 - bardzo mało prawdopodobne,

- 2 - mało prawdopodobne,

- 3 - średnio prawdopodobne,

- 4 - umiarkowanie prawdopodobne,

- 5 - bardzo prawdopodobne,

- dla parametru $C$ :

- 1 - bardzo małe,

- 2 - małe,

- 3 - średnie,

- 4 - duże,

- 5 - bardzo duże,

- dla parametru $V$ :

- 1 - mała,

- 2 - średnia,

- 3 - duża.

Proces oceny ryzyka polega na wyznaczeniu (oszacowaniu) jego liczbowej wartości wg (1) i porównaniu go z przyjętymi wartościami kryterialnymi. Najczęściej spotykaną skalą poziomów ryzyka jest skala trójstopniowa wg zasady [7]:

- ryzyko tolerowane $-r T$,

- ryzyko kontrolowane $-r K$,

- ryzyko nieakceptowane $-r N$. 
Macierz ryzyka dla parametru $V=1$ przedstawić można następująco:

$$
\left|r_{i, j, k}\right|=\left|\begin{array}{ccccc}
1 & 2 & 3 & 4 & 5 \\
2 & 4 & 6 & 8 & 10 \\
3 & 6 & 9 & 12 & 15 \\
4 & 8 & 12 & 16 & 20 \\
5 & 10 & 15 & 20 & 25
\end{array}\right|
$$

Macierz ryzyka dla parametru $V=2$ przedstawić można następująco:

$$
\left|r_{i, j, k}\right|=\left|\begin{array}{ccccc}
2 & 4 & 6 & 8 & 10 \\
4 & 8 & 12 & 16 & 20 \\
6 & 12 & 18 & 24 & 30 \\
8 & 16 & 24 & 32 & 40 \\
10 & 20 & 30 & 40 & 50
\end{array}\right|
$$

Macierz ryzyka dla parametru $V=3$ przedstawić można następująco:

$$
\left|r_{i, j, k}\right|=\left|\begin{array}{ccccc}
3 & 6 & 9 & 12 & 15 \\
6 & 12 & 18 & 24 & 30 \\
9 & 18 & 27 & 36 & 45 \\
12 & 24 & 36 & 48 & 60 \\
15 & 30 & 45 & 60 & 75
\end{array}\right|
$$

Wartość ryzyka oraz każdego z indeksów ryzyka wyznaczono woparciu o założenie, iż w danym rozpatrywanym roku na sieci magistralnej jak i zarówno na sieci rozdzielczej zaistniało , $i$ " zdarzeń awaryjnych, dla których analiza ryzyka wykazała ryzyko na poziomie tolerowanym, ,j” zdarzeń dla których analiza ryzyka wykazała ryzyko na poziomie kontrolowanym oraz, że wstąpiło „,k” awarii, dla których analiza ryzyka wykazała ryzyko na poziomie nieakceptowanym.

Zgodnie $\mathrm{z}$ formułą (1) poszczególne parametrów ryzyka zawarte w kolumnach macierzy dają wynik świadczący o wartości ryzyka awarii na sieci wodociągowej. Następnym etapem, na potrzeby oceny ryzyka, jest porównanie otrzymanych wartości $\mathrm{z}$ kryteriami oraz kategoriami ryzyka zaproponowanymi w tabeli 1:

Tabela 1. Kryteria wartościowania ryzyka

\begin{tabular}{|cc|}
\hline Wartość ryzyka & Kategoria ryzyka \\
\hline $1 \div 10$ & Kontrolowane \\
\hline $11 \div 25$ & Tolerowane \\
\hline $26 \div 75$ & Nieakceptowane \\
\hline
\end{tabular}


The method of identification the failure risk on water supply networks Metoda identyfikacji ryzyka awarii sieci wodociagowych

Analizę wyników można przeprowadzić w oparciu o:

- rozkład procentowy ryzyka wg . kategorii (rodzaju) ryzyka,

- rozkład ryzyka nieakceptowanego,

- rozkład podatności według rozkładu ryzyka nieakceptowanego,

- podanie indeksu ryzyka nieakceptowanego - stosunek liczby ryzyka nieakceptowanego do całkowitej liczby ryzyka w danej kategorii, pokazuje on które z rodzajów ryzyka zmierzają w stronę ryzyka nieakceptowanego.

Poszczególne wartości indeksów ryzyka obliczono wg następujących wzorów:

- Indeks ryzyka tolerowanego $\operatorname{Ir} T$ wg wzoru:

$$
I r T=\frac{\sum_{i} r T_{i}}{\sum r_{T K N}}
$$

- Indeks ryzyka kontrolowanego $\operatorname{IrK} \mathrm{wg}$ wzoru:

$$
I r K=\frac{\sum_{j} r K_{j}}{\sum r_{T K N}}
$$

- Indeks ryzyka nieakceptowalnego $\operatorname{IrN} \mathrm{wg}$ :

$$
I r N=\frac{\sum_{k} r N_{k}}{\sum r_{T K N}}
$$

gdzie:

$$
\sum r_{T K N}=\sum_{i} r T_{i}+\sum_{j} r K_{j}+\sum_{k} r N_{k}
$$

$\sum_{i} r T_{i}$ - suma wartości ryzyka , $i$ " na poziomie tolerowanym w badanym okresie czasu $\Delta \mathrm{t}$, $\sum_{j} r K_{j}$ - suma wartości ryzyka,$j "$ na poziomie kontrolowanym badanym okresie czasu $\Delta \mathrm{t}$ $\sum_{k} r N_{k}$-suma wartości ryzyka „k” na poziomie nieakceptowanym badanym okresie czasu $\Delta \mathrm{t}$

$\operatorname{IrT}$ - indeks ryzyka tolerowanego,

Ir $K$ - indeks ryzyka kontrolowanego,

IrN - indeks ryzyka nieakceptowalnego. 


\section{Przykład aplikacyjny}

Analizowana sieć wodociągowa aktualnie zaopatruje ok. 190 tys. mieszkańców. Wydajność ujęcia wynosi 84 tys. $\mathrm{m}^{3} / \mathrm{d}$, przy czym średniodobowy pobór wody kształtuje się na poziomie ok. 35,6 tys. $\mathrm{m}^{3} / \mathrm{d}$ (stan na rok 2013).

Przykład aplikacyjny wykonano dla sieci wodociągowej (magistralnej i rozdzielczej) o łącznej długości 579,8 km.

$\mathrm{Na}$ podstawie identyfikacji czynników ryzyka oraz szczegółowej analizy awaryjności dla sieci wodociągowej z podziałem na sieć magistralną i rozdzielczą, na podstawie danych z dziennika awarii w roku 2014 wyznaczono liczbę ryzyka na poszczególnym poziomie a następnie wyznaczono poszczególne indeksy ryzyka.

Analizę ryzyka wykonano oddzielnie dla sieci magistralnej (na której odnotowano 33 awarie) oraz rozdzielczej (na której odnotowano 67 awarii) metodą trójparametryczną wg formuly (1).

Analizę ryzyka awarii wykonano w oparciu o wiedzę ekspercką, pracowniczą oraz dostępną literaturę fachową.

$\mathrm{Na}$ podstawie funkcjonującego układu wodociągowego, skutków wywołanych przez każdą z awarii na sieci magistralnej i rozdzielczej, przypisano każdej awarii wagi punktowe dla każdego z parametrów $P, C$ i $V$ wg zasady dla równania (1).

Jako czynnik charakteryzujący każdą $\mathrm{z}$ awarii przyjęto średnicę przewodu na którym wystąpiła awaria. Kryteria opisowo-punktowe dla każdej z awarii na sieci wodociągowej przedstawiono w tabeli 2 i 3.

Tabela 2. Kryteria opisowo-punktowe dla awarii na sieci magistralnej

\begin{tabular}{|cccc|}
\hline Średnica & Parametr $P$ & Parametr $C$ & Parametr $V$ \\
\hline 300 & 2 & 2 & 2 \\
\hline 325 & 1 & 2 & 2 \\
\hline 350 & 2 & 3 & 1 \\
\hline 400 & 5 & 3 & 1 \\
\hline 500 & 3 & 4 & 1 \\
\hline 800 & 1 & 5 & 1 \\
\hline
\end{tabular}

Tabela 3. Kryteria opisowo-punktowe dla awarii na sieci rozdzielczej

\begin{tabular}{|cccc|}
\hline Średnica & Parametr $P$ & Parametr $C$ & Parametr $V$ \\
\hline 100 & 5 & 1 & 3 \\
\hline 110 & 2 & 1 & 3 \\
\hline 150 & 5 & 1 & 3 \\
\hline 160 & 2 & 2 & 2 \\
\hline 200 & 2 & 2 & 2 \\
\hline 225 & 1 & 2 & 2 \\
\hline 250 & 3 & 2 & 2 \\
\hline
\end{tabular}


The method of identification the failure risk on water supply networks Metoda identyfikacji ryzyka awarii sieci wodociagowych

Wykorzystując formułę (1) obliczono wartości ryzyka dla każdej ze średnic. Wyniki zestawiono w tabeli 4 oraz 5.

Tabela 4. Wartości ryzyka awarii na sieci magistralnej

\begin{tabular}{|ccc|}
\hline Srednica & Wartość ryzyka & Kategoria ryzyka \\
\hline 300 & 8 & Tolerowane \\
\hline 325 & 4 & Tolerowane \\
\hline 350 & 6 & Kontrolowane \\
\hline 400 & 15 & Kontrolowane \\
\hline 500 & 12 & Kontrolowane \\
\hline 800 & 5 & Tolerowane \\
\hline
\end{tabular}

Tabela 5. Wartości ryzyka awarii na sieci rozdzielczej

\begin{tabular}{|ccc|}
\hline Średnica & Wartość ryzyka & Kategoria ryzyka \\
\hline 100 & 15 & Kontrolowane \\
\hline 110 & 6 & Tolerowane \\
\hline 150 & 15 & Kontrolowane \\
\hline 160 & 8 & Tolerowane \\
\hline 200 & 8 & Tolerowane \\
\hline 225 & 4 & Tolerowane \\
\hline 250 & 12 & Kontrolowane \\
\hline
\end{tabular}

Na podstawie wyników uzyskanych w tabelach 4 i 5 wyznaczono na podstawie wzoru (5) sumę ryzyka na sieci magistralnej oraz rozdzielczej niezbędną do wyznaczenia indeksów każdego z ryzyka.

Suma ryzyka na sieci magistralnej wynosi:

$\sum r_{\text {TKNmagistala }}=8+4+6+15+12+5=50$

Suma ryzyka na sieci rozdzielczej wynosi:

$\sum r_{\text {TKNrozdzikcza }}=15+6+15+8+8+4+12=68$

Na podstawie sumy ryzyka wyznaczono kolejno ze wzorów (2), (3), (4) indeksy ryzyka. Wyniki zestawiono w tabeli 6 .

Tabela 6. Wyniki analizy różnych rodzajów ryzyka

\begin{tabular}{|cc|cccc|ccc|}
\hline \multirow{2}{*}{ Ip } & $\begin{array}{c}\text { Rodzaj sieci } \\
\text { wodociagowej }\end{array}$ & \multicolumn{3}{|c|}{$\begin{array}{c}\text { Wartość ryzyka } \\
\text { w danej skali }\end{array}$} & \multicolumn{3}{|c|}{ Indeks ryzyka } \\
\cline { 3 - 10 } & $\boldsymbol{r} \boldsymbol{T}_{\boldsymbol{i}}$ & $\boldsymbol{r} \boldsymbol{K}_{\boldsymbol{j}}$ & $\boldsymbol{r} \boldsymbol{N}_{\boldsymbol{k}}$ & $\Sigma$ & $\boldsymbol{I r} \boldsymbol{T}$ & $\boldsymbol{I} \boldsymbol{r} \boldsymbol{I}$ & $\boldsymbol{I} \boldsymbol{N}$ \\
\hline 1 & Magistralna & 3 & 3 & 0 & 6 & 0,34 & 0,66 & 0 \\
\hline 2 & Rozdzielcza & 4 & 3 & 0 & 7 & 0,38 & 0,62 & 0 \\
\hline
\end{tabular}




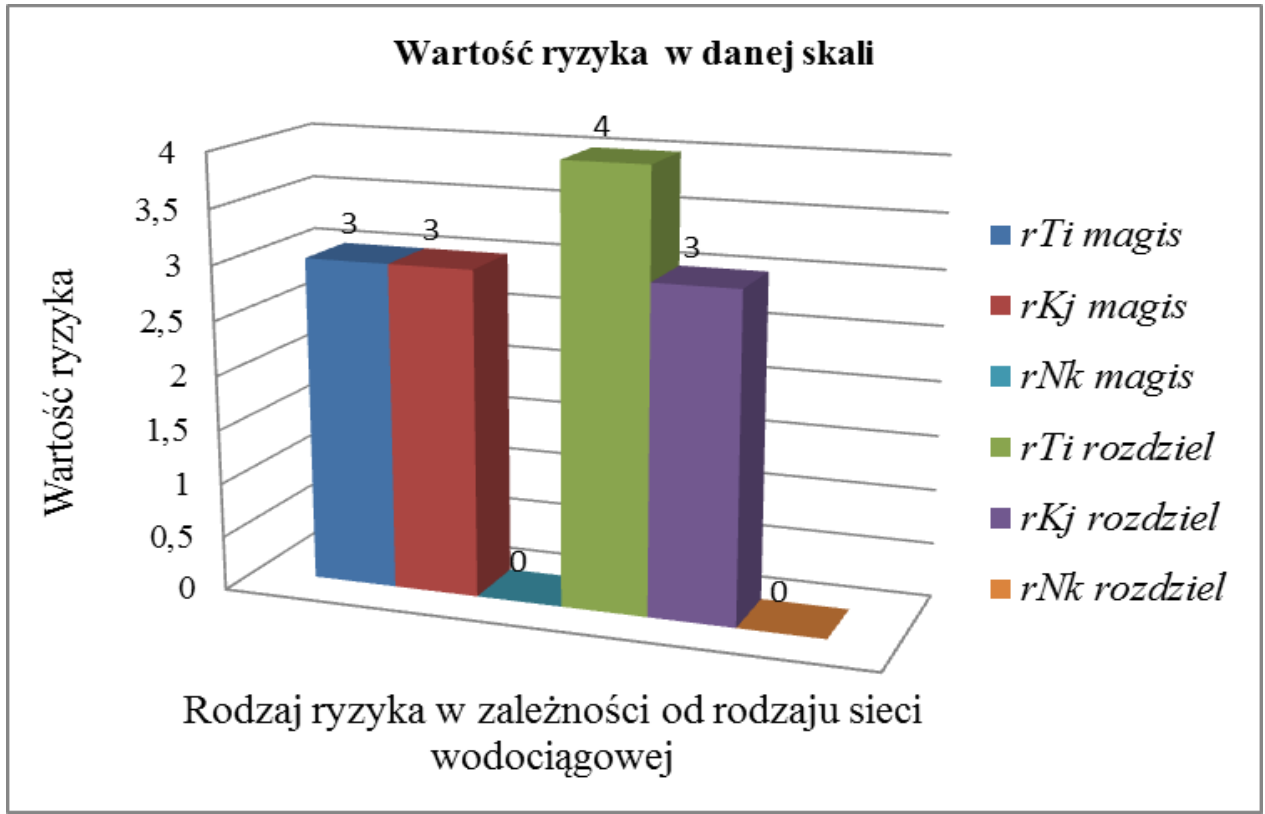

Rys. 1 Prezentacja liczby ryzyka oraz jego rodzaju $w$ zależności od rodzaju sieci wodociagowej

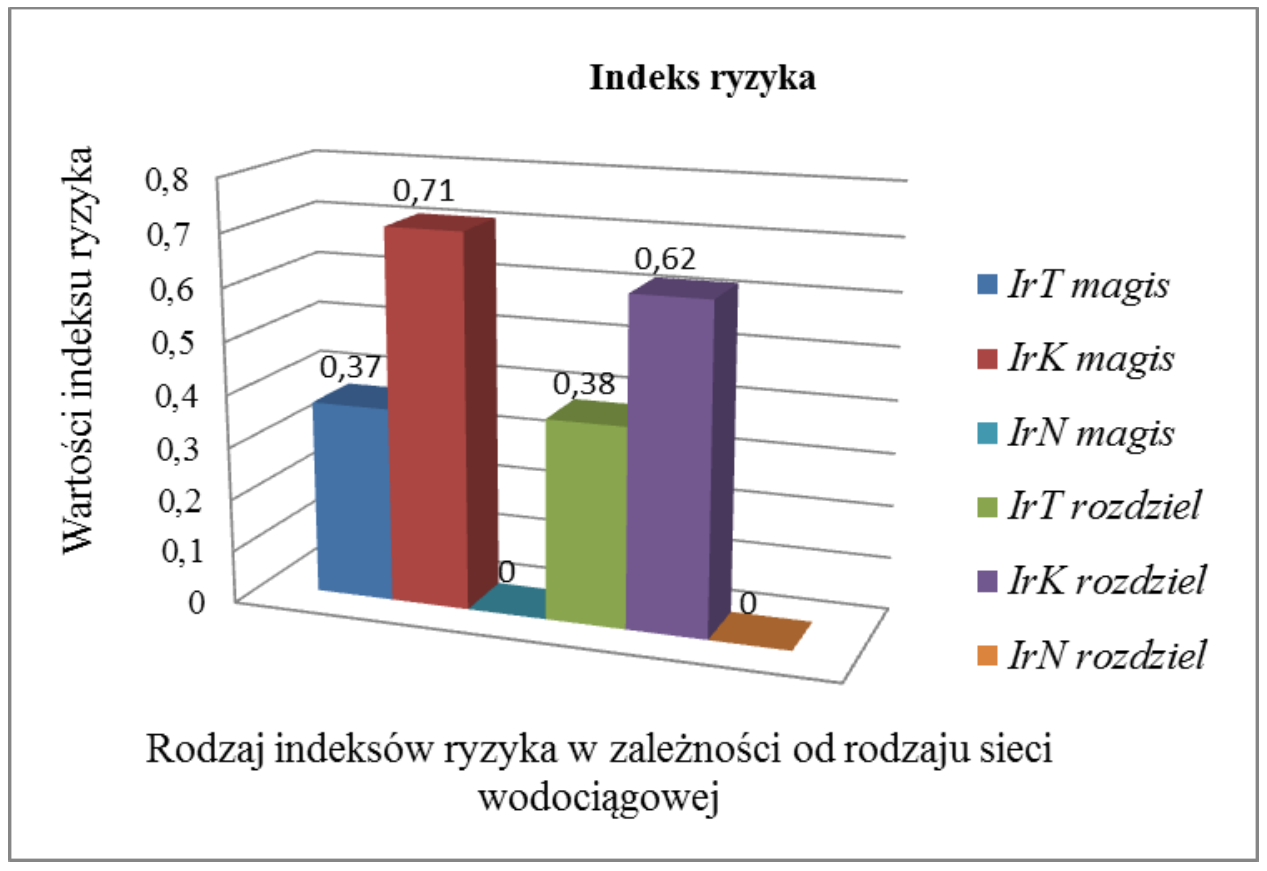

Rys. 2 Prezentacja wartości indeksów ryzyka $w$ zależności od rodzaju sieci wodociagowej 
The method of identification the failure risk on water supply networks Metoda identyfikacji ryzyka awarii sieci wodociagowych

\section{Wnioski}

Zaproponowana metoda pokazuje rozkład procentowy zidentyfikowanych wartości ryzyka. Metoda uwzględnia częstość wystąpienia awarii na przewodzie wodociągowym o konkretnej średnicy, średnie koszty naprawy oraz szacunkowy czas wyłączenia uszkodzonego przewodu $\mathrm{z}$ okresu eksploatacji $\mathrm{z}$ powodu konieczności jego remontu. Wyniki indeksów ryzyka dla poszczególnych typów sieci określają ryzyko awarii w formie procentowej. Metoda pozwala na stworzenie jasnego oraz czytelnego rankingu opisującego awaryjność przewodów wodociągowych. Ponad to może zostać zaadaptowana dla każdego przedsiębiorstwa wodociągowego prowadzącego rejestr awarii.

\section{Bibliografia}

[1] Imran S. A. Sadiq R., Kleiner Y.,, Managing the impact of changing treatment practices on distribution system water quality, WCWWA 60 th Anniversary Conference, Regina, 2008

[2] Kaplan S. Garrick B. J., On the quantative definition of risk Risk Analysis, 1(1)/1981, s. 11-27.

[3] Kleiner Y. Rajani B., Sadiq R., Failure risk management of buried infrastructure using fuzzy-based techniques, Journal of Water Supply Research and Technology - AQUA, International Water Association Publishing, 55(2)/2006, s. 81-94.

[4] Kołowrocki K. Smalko Z., Safety and reliability of a three-state system at variable operation conditions, Scientific problems of machines operation and maintenance, Komitet Budowy Maszyn PAN, 2(166)/2011, s. 47-54.

[5] Papciak D. Zamorska J., Kaleta J., Puszkarewicz A.,, Effect of Manganese(II) on the Time of Biofilm Formation and on the Effectiveness of Ammonium Nitrogen Removal from Water In Biofiltration Process, Polish Journal of Environmental Studies, 2/2009, s. 43-50.

[6] Piegdoń I. Tchórzewska-Cieślak B., Matrix analysis of risk of interruptions in water supply in terms of consumer safety, Journal of KONBiN. 2012, Wydawnictwo Instytutu Technicznego Wojsk Lotniczych, Warszawa. p. 125140.

[7] Rak J., Podstawy bezpieczeństwa systemów zaopatrzenia $w$ wodę, Komitet Inżynierii Środowiska PAN, Lublin, 2005.

[8] Rak J., Selected problems of water supply safety, Environment Protection Engineering, Wroclaw University of Technology, the Department of Environmental Engineering, 35(2)/2009, s. 29-35.

[9] Rak J., A study of the qualitative methods for risk assessment in water supply systems, Environment Protection Engineering, Oficyna Wydawnicza Politechniki Wrocławskiej, 3-4/2003, s. 123-134.

[10] Rak J. Tchórzewska-Cieślak B., Ryzko w eksploatacji systemów zbiorowego zaopatrzenia $w$ wodę, Wydawnictwo Seidel-Przywecki Sp. z o.o., Warszawa, 2013. 
[11] Studziński A., Amount of labour of water conduit repair, Proceedings of the European Safety and Reliability Conference, ESREL 2013, Taylor \& Francis Group, 2014, s. 2081-2084.

[12] Świderska -Bróż M Wolska M., Ocena wtórnego zanieczyszczenia niestabilnej chemicznie wody $w$ systemie dystrybucji, Ochrona Środowiska PZiTS O/Dolnośląski, 4/2005, s. 35-38.

[13] Świderska -Bróż M., Skutki obecności biofilmu w systemach dystrybucji wody przeznaczonej do spożycia przez ludzi, Ochrona Środowiska, PZiTS O/Dolnośląski, 1/2012, s. 9-12.

[14] Tchórzewska-Cieślak B., Risk management system in water-pipe network functioning, Reliability And Societal Safety, Taylor \& Francis, 3/2008, s. 2463-2472.

[15] Tchórzewska-Cieślak B., Water consumer safety in water distribution system, Environmental Engineering III, Dudzińska M. R. Pawłowski L., Pawłowski A., Editor. 2010, Taylor \& Francis Group, London. p. 527-532.

[16] Tchórzewska Cieślak B. Boryczko K., Piegdoń I.,, Possibilistic risk analysis of failure in water supply network, Proceedings of the European Safety and Reliability Conference, ESREL 2014, 2014, s. 1473-1480.

[17] Tchórzewska Cieślak B. Szpak D., A proposal of a method for water supply safety analysis and assessment, Ochrona Srodowiska, 37(3)/2015, s. 43-47.

[18] World Health Organization, Water Safety Plans. Managing drinking-water quality from catchment to consumer, Water, Sanitation and Health. Protection and the Human Environment World Health Organization, Geneva, 2005.

[19] Rozporządzenie Ministra Zdrowia z dnia 13 listopada 2015 r. w sprawie wymagań dotyczących jakości wody przeznaczonej do spożycia przez ludzi (Dz. U. z dnia 27.11.2015 r. poz.1989).

[20] PN-N-18002-2011- Systemy zarządzania bezpieczeństwem i higieną pracy. Ogólne wytyczne do oceny ryzyka zawodowego.

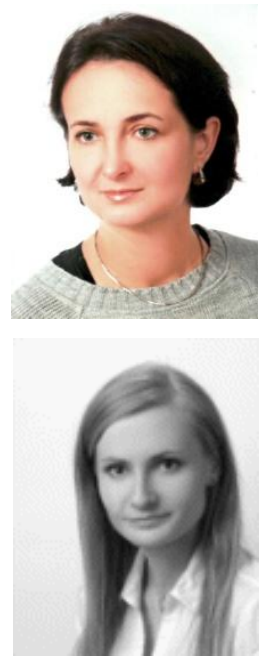

dr hab. inż. Barbara Tchórzewska-Cieślak, prof. PRz pracuje na stanowisku profesora nadzwyczajnego $w$ Politechnice Rzeszowskiej w Katedrze Zaopatrzenia w Wodę i Odprowadzania Ścieków. Zainteresowania naukowe - eksploatacja systemów zbiorowego zaopatrzenia $w$ wodę, niezawodność $i$ bezpieczeństwo systemów inżynierskich, niekonwencjonalne metody analizy $i$ oceny ryzyka. (Udziat 50\%)

mgr inż. Izabela Piegdoń pracuje na stanowisku asystenta w Politechnice Rzeszowskiej w Katedrze Zaopatrzenia w Wode $i$ Odprowadzania Ścieków. Zainteresowania naukowe niezawodność i bezpieczeństwo systemów inżynierskich, techniki informatyczne $w$ zarzadzaniu systemami dystrybucji wody. (Udziat 50\%) 
The method of identification the failure risk on water supply networks Metoda identyfikacji ryzyka awarii sieci wodociagowych 